\title{
Creative Content Marketing In Scientific Publication Management In Industrial Era 4.0
}

\author{
Untung Rahardja ${ }^{1}$, Ninda Lutfiani ${ }^{2}$, Sindy Amelia ${ }^{3}$ \\ 1,2,3Raharja University, Jl. Jendral Sudirman No.40 Modernland, Cikokol, Tangerang \\ e-mail: untung@raharja.info, ninda@raharja.info, sindy@raharja.info
}

\begin{abstract}
Industry 4.0 is a development trend of intelligent industries where all use of sophisticated equipment and are influenced by technological factors that are developing at this time. The emergence of industry 4.0 affects all aspects of the field including the field of marketing. Marketing is a marketing technique or introducing a product to the public to attract a lot of people. The role of Creative Content is needed in the publication of scientific papers in Industry 4.0. Creative Content canfacilitate writers to publish scientific work. Social media is a medium for media creative content in scientific publications. However, the management of online scientific publications or e-journals is stillof little use. To achieve Creative Content in scientific publications the need to conduct research or research to find out and obtain information about the role of creative content in scientific publications. The method used in the research is literature study, design, and mind map. Doing research / researchis not just going to a place but looking for data in a journal is also needed. This study aims to determine the importance of digital content to improve the dissemination of information on publication management or e-journal in its application within the scope of APTISI Transactions on Management (ATM) journals that have been published online. It can be concluded that the role of creative contentin scientific publications is very important, especially in the face of the industrial era 4.0.
\end{abstract}

Keywords: Industry 4.0, ATM, Marketing.

\section{Introduction}

Industry 4.0 is a development trend of smart industries where all use of sophisticated tools and are influenced by technological factors that are developing at this time. The emergence of industry 4.0 affects all aspects of the field including the field of marketing. "Before entering the era of the industrial revolution 4.0 initially started from industry 1.0. The occurrence of the industrial revolution 1.0 in the late 18th century began with the existence of a steam engine. While the 2.0 industrial revolution occurred at the beginning of the 19th century beginning with the implementation of mass production through interchangeable parts production, which created cars, telephones, airplanes. The industrial revolution 3.0 occurred in the early 20th century which began with the emergence of technology and digital. While the 4.0 industrial revolution occurred at this time or this century which began with the emergence of loT (Internet of Things) which was focused on Artificial Intelligence (Artificial Intelligence) "(academia.edu). In the industrial era 4.0 this can also be utilized and developed as a means for media creative content in scientific publications. "Social media is aform of internet development. Data from the Ministry of Communication and Information (Kemenkominfo) in 2013 (kominfo.com), revealed that internet users in Indonesia currently reached63 million from that number, 95 percent of which use the internet to access social networks. Almost every day teenagers access social media just to search for information through Twitter, then deliver their activities through Facebook or path. The results of the survey conducted by the Ministry of Communication and Information (Suara Merdeka, March 27, 2015), showed the 5 most popular social media in Indonesia, namely Facebook with 65 million users, Twitter 19.5 million users, Google+ 3.4 million users, Linkedln 1 million users, and Path of 700 million users [1]. "Social media, which includes online channels for sharing and participating in various activities, represents an increasingly important way for brands to communicate with interesting audience segments (Murdough, 2009). 
Marketers are expected to increase social media advertising spending to $\$ 5$ billion in 2014, up from $\$$ 4.1 billion in 2013, according to eMarketer (2013) [2].

\subsection{Industry 4.0}

Industry 4.0 is a development trend of smart industries where all use of sophisticated tools and are influenced by technological factors that are developing at this time. Industry 4.0 comes from the word "Industry 4.0" which is a project in the advanced technology strategy of the German government that prioritizes computerization of factories.

The term "Industry 4.0" was again discussed at the Hannover Fair in 2011. In October 2012, the Working Group on Industry 4.0 explained the recommendations for implementing Industry 4.0 to the German federal government. Members of the Industry 4.0 working group are recognized as founding fathers and pioneers of Industry 4.0 [3].

Industry 4.0 previously experienced several stages of development starting from industry 1.0, industry 2.0 , industry 3.0 , to industry $4.0[4]$.

1. Industry 1.0 was the first industrial revolution that occurred at the end of the 18th century. At the beginning of the industry 1.0 was characterized by the creation of a steam engine that helped the mechanism of industrial processes. The history of this revolution has been able to increase per economy, and per capita income in each country has increased sixfold over the two centuries after the industrial revolution.

2. Industry 2.0 was an industrial revolution that occurred in the early 19 th century. This industrial revolution was marked by the application of mass production through interchangeable parts production, the use of electric-powered machines and the discovery of industry standardization concepts. In this industrial revolution also began the discovery of telephones, cars, airplanes.

3. Industry 3.0 was an industrial revolution that occurred in the early 20 th century. This industrial revolution was marked by the emergence of digital technology and the internet. In this revolutionary era, all systems changed to automatic computer-based, and not controlled by humans.

4. Industry 4.0 is an industrial revolution that is happening in this century. This industrial revolution was characterized by the emergence of a cyber-physical system. In this era of industry began to use the virtual world, in the form of human, machine and data connectivity. Internet Of Things (IoT) is a name term used today. In the industrial era 4.0 focused on artificial intelligence (Artificial Intelligence), resulting in super computers, smart robots, vehicles without drivers, genetic editing, and neurotechnology development.

\subsection{Creative Content}

Creative content is writing, photos, or videos created aimed at attracting a large audience. In the digital age creative content is the key to success in marketing. Creative requires content as a media link between business and the public. Content that is delivered precisely and in accordancewith the target audience will make the content quality. Creative content is not only used in the business field. In the management of scientific publications creative content has an important role. Social media is a creative content media that can be used for the management of scientific publications. Because using creative content makes it easier to find out about journal submission [5].

\subsection{Marketing}

Marketing is a marketing technique or introducing a product to the public to attract a lot of people. According to Kotler and Armstrong (2008) marketing strategy is the logic of marketing where business units hope to create value and benefit from relationships with consumers. Initially marketing still used the ATL (Above The Line) or BTL (Below The Line) method [6]. With the Industrial Revolution 4.0 can change marketing methods into digital technology. using Omnichannel, Multi-form, and Multiplatform. In scientific marketing publications can also be done, because with the marketing of scientific works can be known by the public. Using social media is one example of digital marketing.Before doing marketing using social media, a strategy is needed [7]. 
1. Focus on one social media

2. Build credibility

3. Focus on the target

4. Building relationships on social media

5. Take into account time and money

\section{Research Method}

The research method is needed by the author to find out what results are obtained during conducting research. During conducting research methods used by the author for a journal are literature studies, mind mapping, and design methods. Where data and information obtained comes from the internet in the form of articles or in the form of quotes from a journal. And also the author uses the mind mapping method where the data obtained comes from the author's thoughts to solve a problem. And also the last method used is the design method, where a method or step is carried out in a design process, this method is needed to facilitate the designer in developing designideas.

A. Literature review

Library Studies is a technique of collecting data by reviewing various books, literature, notes, and various reports relating to the problem that you want to solve. (Understanding literature according to Nazir 1988) [8]. Before conducting research, library studies have a purpose.

- Finding a problem to study

- Look for information that is relevant to the problem to be studied.

- Review some basic theories that are relevant to the problem to be studied.

- Looking for a theoretical basis which is a guideline for problem solving and thinking approaches for the formulation of hypotheses to be tested in research.

- Deepen the knowledge of researchers about the problems and fields to be studied. Review the results of previous research that has to do with the research that will be conducted.

- Examining the results of previous studies directed at some or all of the elements of research, namely: the purpose of research, methods, analysis, main results and conclusions.

- Get information about which aspects of a problem have been researched to avoid investigating the same thing [9].

\section{B. Mind Mapping}

Mind Mapping is a technique that is used to take notes, and utilize the ways of brain performance. The mind mapping technique was introduced by Tony Buzan. He is a prolific expert and writer in the fields of psychology, creativity and self-development. According to Caroline Edward mind mapping is the most effective and efficient way to enter, store, and extract data from the brain. This one system works according to the workings of the human brain, so it is expected tooptimize the potential of our brain. Mind mapping has benefits [10].

- The main theme of an information is clearly illustrated because of its position in the middle.

- The relationship of each information can be easily identified. In addition, the level of interest in information is very well identified.

- New information can be combined without having to change the mind mapping structure. This will help humans remember new information.

- Every mind mapping has unique characteristics that help humans remember new information

- Speed up the memory process because you only use keywords.

And the following is mind mapping that is made to solve problems in a study. 


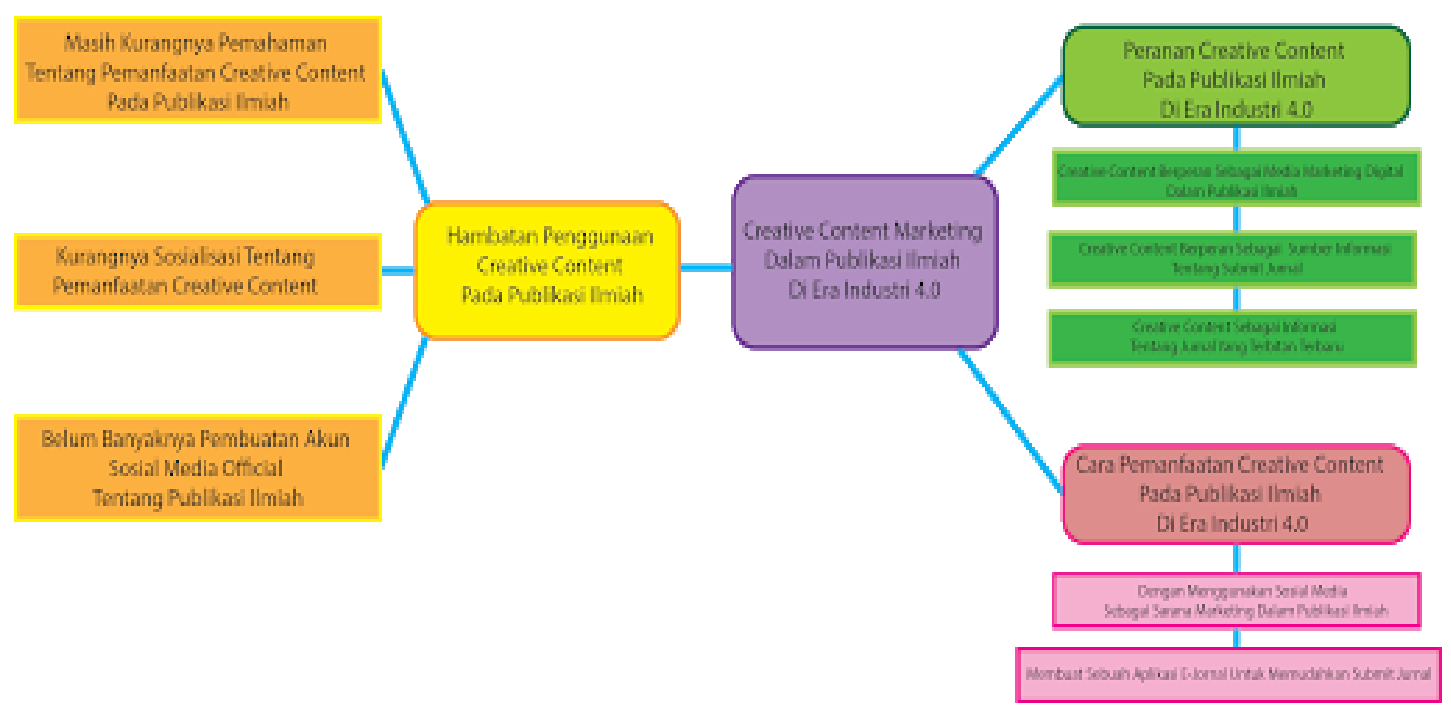

Figure 1. Mind Mapping

C. Design Method

The design method is a method or step carried out in a design process, this method is needed to facilitate the designer in developing design ideas [11]. In order to avoid mistakes in making the drafting method there are several steps that must be done first such as.

1. The background of the design problem is what lies behind this design. It starts with an explanation of a broader problem, generally related to the design of this title. Followed by explaining to the core of the problems related to the object of this design specifically.

2. Data identification is a process that aims to identify all data from survey results. Data identification includes: company data or manager, product data, and data and marketing analysis.

3. The analysis used is SWOT. SWOT analysis is a review of strengths, weaknesses (Weaknesses), opportunities (Opportunities), and challenges (Threads). From this data analysis, it can be concluded simply how important the problem (product) is chosen as the media for the promotion.

4. Synthesis comes from English, which means alloy or combination. The synthesis in this design is a combination of problems that exist on the background of design problems that have been summarized in data analysis.

5. The design concept according to Sanyoto (2006: 62) includes: Media planning includes goals, strategies, programs and media costs. Creative planning includes goals, strategies, programs and creative costs, and design visualization includes goals, strategies, and design / layout programs [12]. 


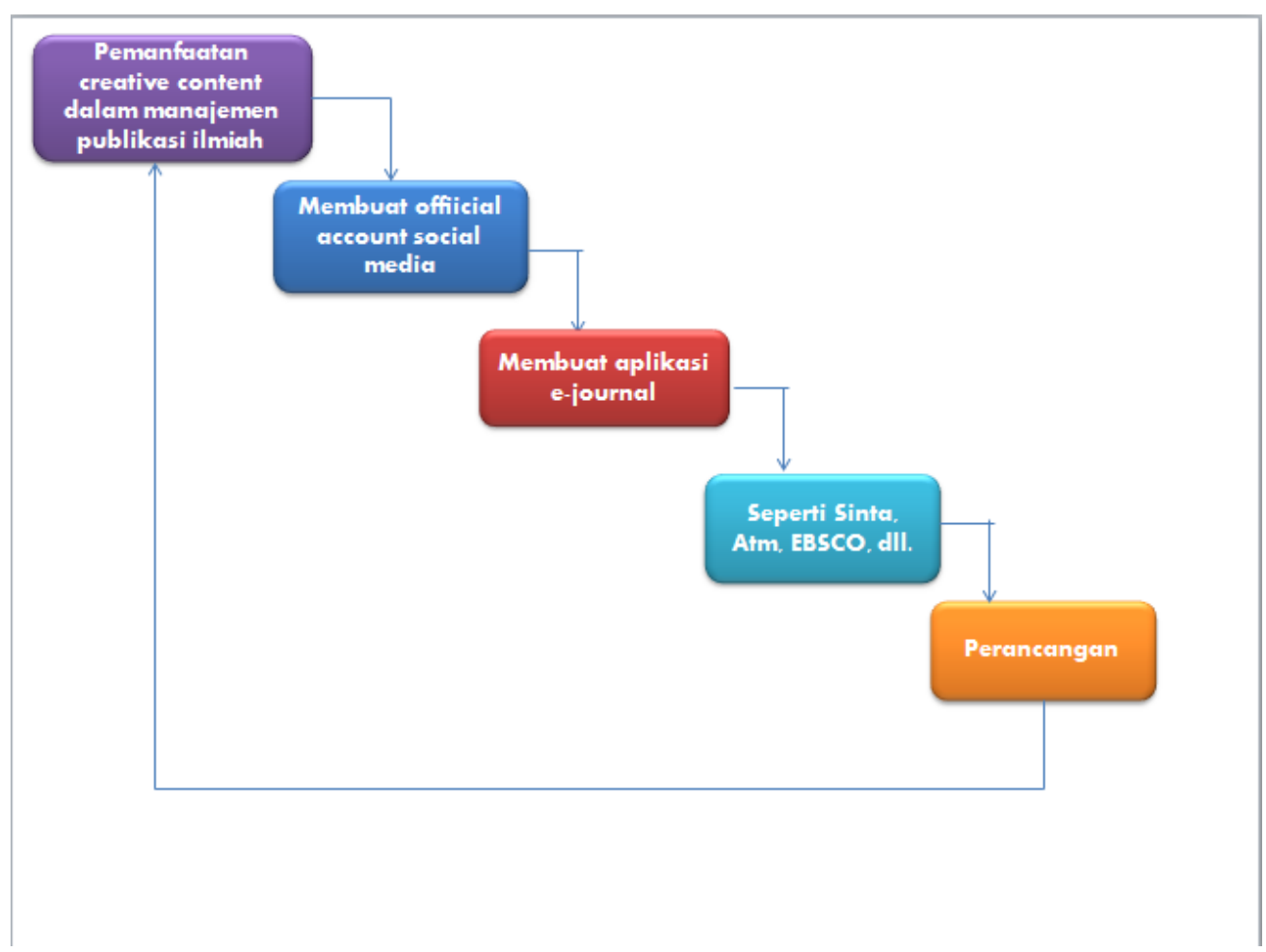

Figure 2. Design Method

\section{Results and Analysis}

During the research, the results and discussion will be explained in this third chapter. In knowing targets and the role of creative content marketing in scientific publications. And know the comparison of the percentage of the community before using a marketing strategy and afterwards. Then obtained a result of marketing scientific publications using creative content in the form of social media, which will be developed and maximized. The application of creative content in scientific publications can be carried out by universities and universities.

A. The role of creative content in scientific publications in industry 4.0

In the industrial revolution era 4.0 management of scientific publications using creative content is very influential, because nowadays people like something related to digital. One of the creative content, is a digital product in the form of a content. Creative content is usually in the form of a video or social media. The role of Creative content in scientific publications is as follows.

1. Creative content acts as a digital marketing media

2. Creative content acts as a source of information about journals

3. Creative content acts as a source of information on the latest journal publications

4. Creative content acts as a media marketing publication in the social media scope

B. How to use creative content in scientific publications in the industrial era 4.0

1. By using social media as a means of marketing in scientific publications.

In the industrial revolution era 4.0 social media has an important role in the media of marketing or promotional means, because currently a number of people use social media more often. For example, Twitter has 55 million 
incoming messages every day [17]. The process of processing tweet data to get information requires a method that can find patterns of linkages and classify these tweets, one of which uses sentiment analysis. Sentiment analysis is done to classify data into positive, negative and neutral classes. Therefore this is a golden opportunity for everyone to do promotion or marketing. Promoting or marketing using social media is currently a trend or many do it, usually promoted various kinds of clothing, food, and electronic devices. Apart from not only clothes, food and electronic devices, journals or scientific works can also be promoted through social media. One example that uses social media as a management of scientific publications is ATM (APTISI Transactions on Management) wherein there is some information about submitting journals or papers. With an official social media account, it can make it easier to find information about submitting journals or papers made.

(0) Instagram
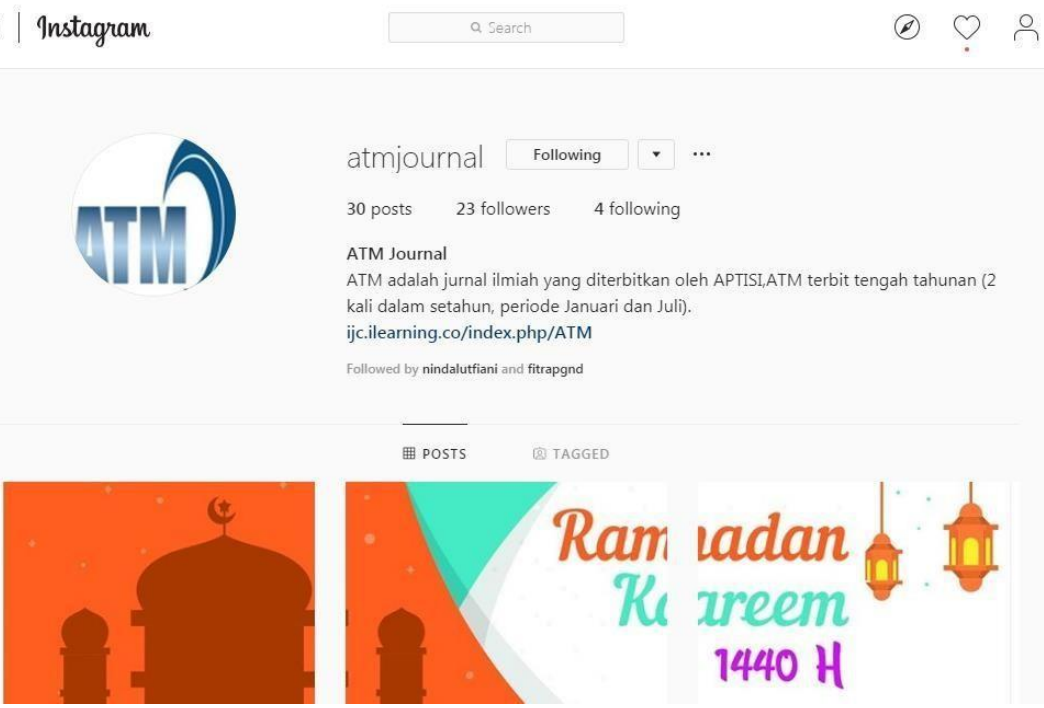

Figure 3. Social Display Of ATM Journal Media

(0)
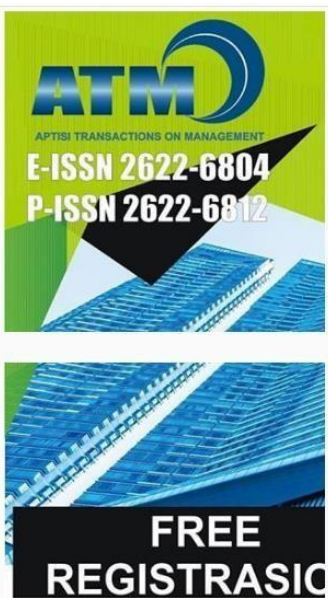

FOR MORE IN UFOQ a Search
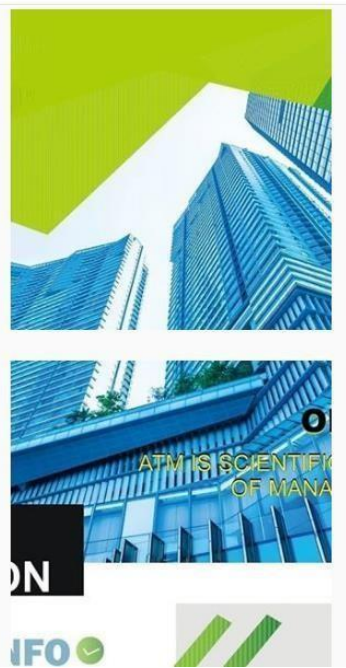

(2) $0 \stackrel{\circ}{\circ}$
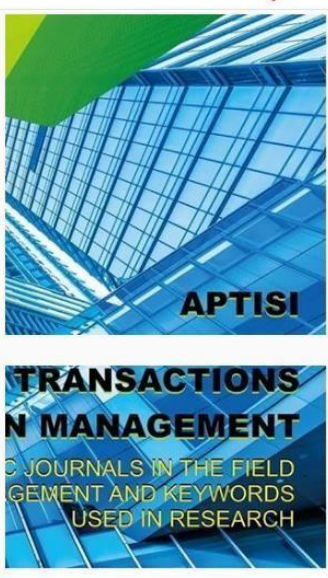

CALL FOR

Figure 4. Social Display Of ATM Journal Media 
2. By making it an electronic journal application or an OJS-based journal (Open Journal System).

In the era of the industrial revolution 4.0, of course, everything was based on electronic or digital forms such as applications such as E-money, M-banking, Tix.id, etc. This electronic-based application is not only for transactions, but can also be used for the management of scientific publications. OJS or Ejournal is also a result of creative content marketing in the management of scientific publications. Applications can also be made in scientific publications, to make it easier for writers to submit and find out more fully without having to open a laptop.

\section{EBSCO}

EBSCO is an e-journal that provides information for researchers, centered on Ipswich, USA lecturers and students as well as consulting services and the latest technology to manage and access quality content, in print editions, e-journals, e-packages, researchdatabases, and e-book [13]. At present many libraries organize research and look for new ways to manage their collections more efficiently. EBSCO Information Services has developed and found solutions, including EBSCO A-to-Z and Link Source, and also management solutions such as EBSCONET, EBSCONET ERM Essentials and EBSCO MARC Updates. This service offers unmatched integration to help librarians save time and money while empowering users.

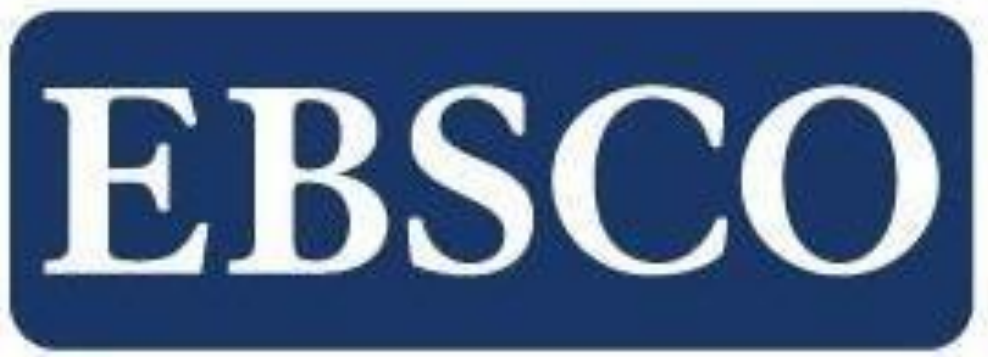

Figure 5. OJS EBSCO

2. SINTA (Science and Technology Index)

Sinta (Science and Technology Index) is a portal containing performance measurement of Science and Technology whichincludes such as the performance of researchers, writers, authors, journal performance and the performance of science and technology institutions (according to Ristekdikti official page) [14]. Currently listed on SINTA there are 4,692 Affiliations and 159,692 authors, and affiliations that get the most scores are Universita Indonesia. Since 
2017 SINTA released a list of top 100 affiliations, University of Indonesia ranked first with 9,262 scores. While overal the University of Indonesia got a score of 85,465 . In order to make it easier for users, there is a feature in management like in the source [15].

1. Citation

In the Sinta official website page there is a Citation section which displays the h-index in the period of time for Google Scholar and Scopus.

2. Networking

In the Sinta official website there is also a networking section, where visitors to the official Sinta page can find out networking with other researchers who have collaboratedwith you.

3. Research Output

Research Output contains the journal articles, books and seminar articles that you have produced. While in the Score section, you can see indexes in Scopus, Google Scholar and InaSTI.
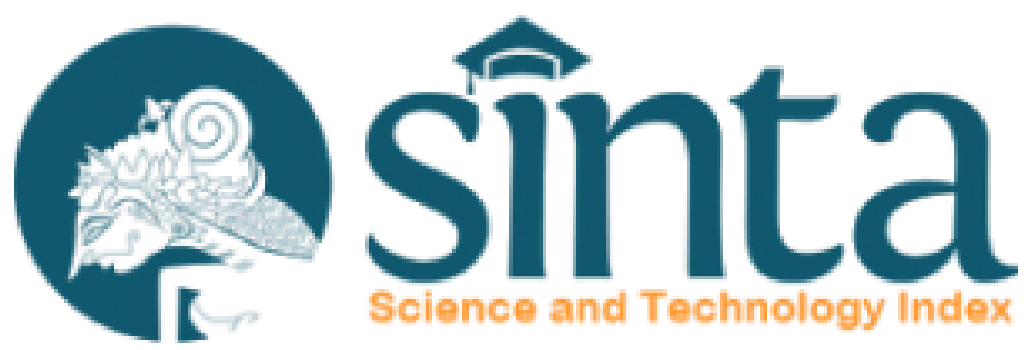

Figure 6. OJS Sinta

4. ATM (APTISI Transactions on Management)

"ATM is a scientific journal published by APTISI (Association of Indonesian Private Universities), to facilitate the results of the academic journal of the Academic Society in the field of management in the face of the digital era in Indonesia.

ATM scientific journal is a scientific journal in the field of Management Information Systems which contains scientific writings on pure and applied research in the fields of Business Management, Accounting, Information Management and the application of science in other related fields.

ATM has obtained an official ISSN number from LIPI (Indonesian Institute of Sciences), with ISSN number 26226804 (online) and ISSN 2622-6812 (print). ATMs are published in the middle of the year ( 2 times a year, January and July periods) [16]. ATM (Aptisi Transaction On 
Management) has been indexed by LIPI (Indonesian Institute of Sciences), Google Scholar, Index Copernicus, Ijc, Indonesia One Search, Crossref, BASE, Mendeley, Garuda, Neliti.

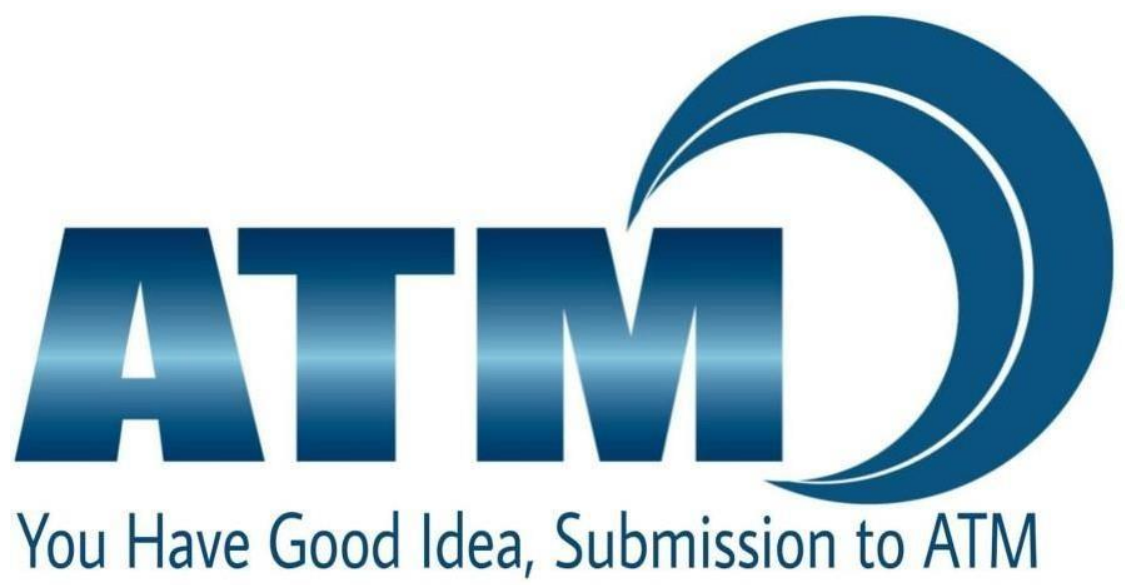

Figure 7. OJS ATM

C. Barriers to the use of creative content in scientific publications

in the industrial era 4.0 the role of creative content is very important because it supports the publication of scientific work. Unfortunately for the achievement of the creation of creative content in the management of scientific publications there are several obstacles or obstacles such as:

1. There is still a lack of understanding of the use of creative content in the management of scientific publications

2. Lack of socialization regarding the use of creative content in the management of scientific publications

3. Not many people have made social media official accounts specifically about journals

\section{Conclusion}

Method E-Budgeting is one example of innovation industry 4.0 which is frequently used in the world of Government. This method is a new method that will get rid of the old functions such as excel. With this e-budgeting, financial information system activities provide ease in a variety of ways, including the following :

1. Simplify admin in making the report or details of financial costs so it can be evaluated as soon as possible by the leadership directly.

2. It can be accessed anytime anywhere publicly, dengan syarat harus terkoneksi dengan jaringan internet.

3. To prevent manipulation of the budget funds so that is not the case of embezzlement of money. 


\section{References}

[1] Cid, G. P., \& Gil-García, J. R. (2004). ENACTING E-BUDGETING IN MEXICO (1) Public Finance \& Management, 4(2).

[2] Ashley, Christy and Tuten, Tracy, 2015. "Creative Strategies in Social Media Marketing : An Exploraty Study Of Branded Social Content and Consumer Engagement "Volume 32.

[3] Wikipedia, "PENGERTIAN INDUSTRI 4.0", 2019. https://id.wikipedia.org/wiki/ Industri 4.0

[4] Ayudiah,Syafaati, "REVOLUSI INDUSTRI 1.0 - 4.0", 2019. http://www.academia. edu/37491240/REVOLUSI INDUSTRI DARI GENERASI 1.0 HINGGA 4.0

[5] Indonesia, DM, "PENGERTIAN CREATIVE CONTENT", https://www.dmindonesia. com/creative-content.html

[6] "Strategi Pemasaran: Pengertian, Fungsi, Tujuan, Konsep, dan Contohnya". https:// www.maxmanroe.com/vid/marketing/pengertian-strategi-pemasaran.html

[7] Nov,Kari, 2019. " PENGERTIAN MARKETING DIGITAL”, https://karinov.co. id/mengenal-apa-itu-digital-marketing/

[8] "Pengertian Studi pustaka". http://www.definisimenurutparaahli.com/pengertian-studi- pustaka/

[9] “Pengertian Kepustakaan” , 2016. http://www.transiskom.com/2016/03/pengertian- studikepustakaan.html

[10] "Teknik Mencatat Kreatif dengan Mind Mapping". https://www.muhammadnoer .com/teknik-mencatat-kreatif-dengan-mind-mapping/

[11] “Metode Perancangan”. http://etheses.uin-malang.ac.id/1283/7/09660041_Bab_3.pdf

[12] Agita, Puspita. "Perancangan Company Profile Berbasis Web untuk Mempromosikan Tanjung Plaza Hotel Tretes ".

[13] Dwi Lestari, Arini, "PENGERTIAN EBSCO”, 2018. https://timur.ilearning.me /2018/07/16/findout-indexation-service-ebsco/

[14] Amin, Muhammad . "Mengetahui apa itu sinta, Bagaimana Cara Mendaftar dan Fungsinya sebagai alat pengindeks Publikasi”. https://muh-amin.com/mengetahui- apa-itu-sintabagaimana-cara-mendaftar-dan-fungsinya-sebagai-alat-pengindeks- publikasi/

[15] "Affliations" http://sinta2.ristekdikti.go.id/affiliations

[16] “ATM (Aptisi Transactions on Management)". https://atm.aptisi.or.id

[17] T F.Ratnawati and E. Winarko, "Sentiment Analysis of MovieOpinion in Twitter Using Dynamic Convolutional Neural Network Algorithm, Indonesian Journal of Computing and Cybernetics System(IJCCS), 2018, 12 (1), https://doi.org/10.22146/ijccs.19237 